\title{
CLINICO-EPIDEMIOLOGICAL PROFILE AND OUTCOME OF POISONOUS SNAKE BITES IN CHILDREN USING THE WHO TREATMENT PROTOCOL IN WESTERN NEPAL
}

\author{
Kiran Mani Paudel, V P Poudyal, Rajan Bikram Rayamajhi, \\ Shyam Sundar Budhathoki
}

\begin{abstract}
Background: Snake bite among children is an important public health problem in many tropical and subtropical countries. Limited studies are found on snake-bite in Nepal using the WHO snake-bite management guidelines. This study assessed the clinico-epidemiological profile and their outcome in snake-bite among children using the WHO Guidelines for treatment of snake bite.
\end{abstract}

Methods: This is a descriptive study among 75 children less than 14 years of age admitted in Emergency Room (ER) of Lumbini Zonal Hospital from 2011-2012 with the history of poisonous snake bite.

Results: More than half (56\%) of the cases were males and 3/5th $(58 \%)$ were above 10 years of age. About $40 \%$ of the patients were brought to ER within 6-12 hrs of snake bite. Common site of snake-bite was lower limbs (32\%) followed by upper limbs (29\%). Abdominal Pain (44\%) was observed as most common sign/symptom of snake-bite poisoning after local pain followed by ptosis $(17.3 \%)$. The case fatality rate (CFR) was $16.0 \%$.

Conclusion: Use of WHO treatment guideline for snakebite case management among children showed low CFR. However further studies need to done to compare the treatment outcomes between WHO guideline and the National Guidelines among snakebite cases among children.

Key words: Case fatality rate, Envenomation, snake bite Nepal

\section{Introduction:}

The incidence of snakebite is high in warmer regions where snakes are found abundantly and agriculture is the main economic source. ${ }^{2}$ In the South East Asia Region, snakebite is a common medical emergency and an important cause of hospital admissions. There are 200 poisonous species of snakes from the known 3000 species of snakes around the world.

All the snakebite cases do not reach the health facility, comprising of non poisonous snake bites, less severe cases, and the cases that have died in the field. There are reported cases of seeking treatment from traditional healers. Thus data available so far cannot give precise data on the snakebite incidence. There is an estimate of more than 5 million snakebites associated with more than 100 thousand deaths due to snakebites each year. South East Asia and Sub Saharan Africa report highest burden of snakebite in the world. Estimated 4 million snakebites are reported from Asia alone.

While Cobra and Krait are the commonest poisonous snakes in the terai region of Nepal, there are 22 species of snakes that are known to be poisonous. Annual morbidity due to snake bite is $162 / 100,000$ people in Nepal. There are 1000 deaths in hospital every year from an estimated 20,000 snake bites that 
occur each year in Nepal. ${ }^{6}$ Before the introduction of the National protocol for the management of snakebite in 2003, the case fatality of poisonous snakebite was as high as $58 \%$ in Nepal. The management of snakebite before the protocol was released varied from center to center. ${ }^{8}$ The case fatality rate (CFR) among the snakebite in children was reported as $25 \%$ even after the introduction of the national protocol for treatment of snakebite in Nepal.

After the implementation of the National Protocol in 2007 in India has resulted in lowering the morbidity due to snakebite and expenditure related to snakebite treatment. ${ }^{17,18}$ The WHO guideline on treatment of snakebite for the South East Asia has been released for use for use by countries for the management of snakebite in the region. ${ }^{19}$ Studies reporting on the use of WHO guidelines for snakebite among children was not found in context of Nepal. Hence this study was conducted to assess the socio-epidemiological profile and evaluate the outcome of snake bite poisoning with the use of WHO 2010 guidelines in Western Nepal.

\section{Materials and Methods}

A Cross sectional study was conducted among the under 14 years children presenting in the emergency department of Lumbini Zonal Hospital, a tertiary referral hospital in western Nepal. Total snake bite cases recorded at Lumbini Zonal Hospital during the study period were 2318, out of which 297developed signs and symptoms of envenomation. Of which 75 patients belonged to less than 14 years of age which were included in this study. The study was conducted over a period of 1 year from 2011 to 2012. We included children 14 years and below who showed signs of envenomation. Snakebite cases that were brought dead cases and referred cases of snakebite were excluded from the study. Informed consent was taken prior to the study after explaining the objective of the study to the patient's guardian. Patients were treated by the clinicians and the paramedics using WHO snake envenomation management guidelines. Anti-snake venom manufactured by Haff kine Pharmaceutical Company, Bombay which was distributed by Ministry of Health and Population, Epidemiology and Disease Control Division for government health centers were used for the treatment of the snakebite cases. The permission was taken from the Medical Superintendent of the Hospital to conduct the study. The data were entered in Microsoft Excel 2007 and analyzed using SPSS 17.0 version.

The diagnosis of snake-bite was established on the basis of a history, clinical examination of the patient, observation of the killed snake if available or recognition of the snakes by patient / observers. Snake bite cases admitted in the observation ward were monitored for eight hours to rule out the signs of envenomation. Those who developed signs of envenomation with evidence of neurotoxicity like ptosis, external ophthalmoplegia, respiratory paralysis and other signs of hemotoxic poisoning-were managed with ASV according to the WHO guidelines 2010.

As per the guidelines, 10 vials of polyvalent anti-snake venom (ASV) serum were administered by intravenous infusion over an hour to patients with signs of envenomation. Among those with no improvement in ptosis, another 10 vials of ASV repeated over another two hours and then decreased to 2 vials infused slowly with reference to body mass. Similarly, intravenous fluids and antibiotics were also given to children on the basis of body weight.

\section{Results}

More than half $(56.0 \%)$ of the children were male. About 58.8\% were from the age group 10-14 years. Among the patients, it was observed that most of the patients $(89.3 \%)$ belonged to low socioeconomic background 
with poor housing and surrounding making them vulnerable to snake bite.

Table1: Characteristics of patients with poisonous snake bite $(n=75)$

\begin{tabular}{|l|l|l|l|}
\hline $\begin{array}{l}\text { Characteris } \\
\text { tics }\end{array}$ & $\begin{array}{l}\text { Categori } \\
\text { es }\end{array}$ & $\begin{array}{l}\text { Numb } \\
\text { er (n) }\end{array}$ & $\begin{array}{l}\text { Percenta } \\
\text { ge (\%) }\end{array}$ \\
\hline \multirow{2}{*}{ Gender } & Male & 42 & 56 \\
\cline { 2 - 4 } & Female & 33 & 44 \\
\hline \multirow{2}{*}{$\begin{array}{l}\text { Age group } \\
\text { (years) }\end{array}$} & $<10$ & 31 & 41.33 \\
\cline { 2 - 4 } $\begin{array}{l}\text { Socio- } \\
\text { economic } \\
\text { status }\end{array}$ & $\geq 10$ & 44 & 58.67 \\
\cline { 2 - 4 } & Low & 67 & 89.3 \\
\hline
\end{tabular}

More than half $(58.6 \%)$ of the snakes responsible for bites in our study were unknown followed by Krait (27\%) and Cobra $(15 \%)$ as seen in fig 2. Above mentioned known bites, were presented to ER with the dead snake or as according to the observers. It was found that more than $1 / 3^{\text {rd }}$ of the patients were brought to hospital within 6-12 hours of snake bite while $20 \%$ of cases were brought to ER within $6 \mathrm{hrs}$ of snakebite.

It was seen that lower limbs $(32 \%)$ and upper limbs $(29.33 \%)$ were commonest site for snake bite among the patients.

Table 2: Distribution of patients according to type of snake bite, bite site, time to reach hospital after bite

\begin{tabular}{|l|l|l|l|}
\hline $\begin{array}{l}\text { Characteris } \\
\text { tics }\end{array}$ & $\begin{array}{l}\text { Categori } \\
\text { es }\end{array}$ & $\begin{array}{l}\text { Numb } \\
\text { er (n) }\end{array}$ & $\begin{array}{l}\text { Percenta } \\
\text { ge (\%) }\end{array}$ \\
\hline \multirow{4}{*}{$\begin{array}{l}\text { Type of } \\
\text { snake bite }\end{array}$} & Krait & 20 & 26.67 \\
\cline { 2 - 4 } & Cobra & 11 & 14.67 \\
\cline { 2 - 4 } & $\begin{array}{l}\text { Unknow } \\
\mathrm{n}\end{array}$ & 44 & 58.67 \\
\hline Bite sites & $\begin{array}{l}\text { Lower } \\
\text { limbs }\end{array}$ & 24 & 32 \\
\cline { 2 - 4 } & $\begin{array}{l}\text { Upper } \\
\text { limbs }\end{array}$ & 22 & 29.33 \\
\cline { 2 - 4 } & Head & 5 & 6.67 \\
\cline { 2 - 4 } & Body & 4 & 5.33 \\
\cline { 2 - 4 } & Others & 20 & 26.67 \\
\hline Time gap & $1-6$ & 15 & 20 \\
\cline { 2 - 4 } between bite & $6-12$ & 30 & 40 \\
\hline
\end{tabular}

\begin{tabular}{|l|l|l|l|}
\hline $\begin{array}{l}\text { and arrival } \\
\text { (hours) }\end{array}$ & $12-18$ & 13 & 17.33 \\
\cline { 2 - 4 } & $>18$ & 17 & 22.67 \\
\hline
\end{tabular}

As shown in Table 3, following snake bite, pain abdomen (44\%) was the most common clinical presentation after the local pain followed by vomiting (27\%) and ptosis $(22.67 \%)$. Only one patient was found unconscious. The number of ASV used ranged from 10-38 vials with average of 24.37 vials.

Table 3: Distribution of Sign / Symptom of envenomated patients in ER $(n=75)$

\begin{tabular}{|l|c|c|}
\hline Characteristics $^{\mid}$ & Frequency $^{*}$ & $\mathbf{\%}$ \\
\hline Local pain & 75 & 100 \\
\hline Pain abdomen & 40 & 53.3 \\
\hline Ptosis & 17 & 22.7 \\
\hline Vomiting & 20 & 26.7 \\
\hline $\begin{array}{l}\text { Difficulty in } \\
\text { breathing }\end{array}$ & 15 & 20.0 \\
\hline Salivation & 10 & 13.3 \\
\hline Throat pain & 7 & 9.3 \\
\hline $\begin{array}{l}\text { Swallowing } \\
\text { difficulty }\end{array}$ & 6 & 8.0 \\
\hline Slurring speech & 3 & 4.0 \\
\hline Unconsciousness & 1 & 1.4 \\
\hline *Multiple responses
\end{tabular}

Of which 75 snakebite cases in the study, there were 12 deaths among the children during treatment resulting in a case fatality rate (CFR) of $16 \%$.

\section{Discussion:}

Snakebite among the children in our study occurred more among the above 10 years of age. This finding is similar to other studies. ${ }^{12}$, ${ }^{19}$ Children above 10 years engage in outdoor activities more compared to the younger children. ${ }^{22}$ Findings from retrospective study in Western Nepal are in line with our study findings, where male children were more affected by snakebite. ${ }^{22}$ This finding is seen in other previous studies as well. ${ }^{12,} 13,19-21$ This observation could be due to male children playing and working outside with sleeveless shirts more frequently than their female counterparts. 
In this study, the highest incidence of snakebite poisoning was seen during the months of June, July and August which corresponds to the monsoon season in Nepal. This is also a hot season and the snakes come out of their shelter due to increased humidity and temperature. This seasonal pattern of poisoning was seen in other studies as well..$^{9,14,15,21}$

The study found that the most common site for snake bite were upper limbs and lower limbs. This finding is comparable to previous studies. $9,10,12,18,20,21$ This may be because the children have accidently stepped over the snake while walking and playing and also the curious young children, while playing, put their fingers and hands into the blind holes or pits where the older children may come across the snakes when they are cutting the grass. Abdominal pain followed by ptosis as a common sign was also reported by a previous study. $^{12}$

Ptosis is easily noticeable by the health workers as well as the family members. A fifth of the children developed respiratory distress in our study which is similar to a previous study. ${ }^{22}$ Early administration of anti snake venom is very important in management of cases with poisonous snake bite to reduce the development of respiratory distress.

The average number of vials of ASV used during treatment was 24.37 vials per case. Studies in Nepal have reported '19.6 vials per case $^{20}, 14.4$ vials per case 12 and 18.2 vials per case. ${ }^{22}$ These differences in numbers of vials of anti snake venom vials could not be further investigated at the moment. Case fatality rate (CFR) was high $(16 \%)$ in this study. This finding is in agreement with earlier studies $^{12,14,15}$. The total case fatality rate in different studies before the introduction of WHO protocol ranged from 3 to $58 \%$. The CFR in our study can be explained as children are at a greater risk of severe envenomation due to their smaller body size and volume for venom distribution, and outdoor playing behaviors. ${ }^{3}$ Secondly, in this study, only the poisonous snakebite cases have been included. Anti snake venom is more effective when delivered within 4 hours of the bite. ${ }^{3}$ More than 3/4th of the children in our study were brought for treatment after 6 hours of the snakebite.

With use of WHO guidelines, the CFR in our study was $16.0 \%$, which is lower than the CFR of $28.2 \%$ in a study among 301 snakebite cases using the national snakebite treatment protocol.

The use of WHO guidelines for the management of snake bite resulted in a lower CFR among the snake bite cases in children. There however is need for further studies using the WHO guidelines among the children to generate evidence on the applicability of WHO guideline for snakebite management among children in the Nepalese context.

\section{Conflict of Interest: None}

Funding: None

\section{Acknowledgment}

We would like to thank Medical Superintendent of our hospital Dr Tara Nath Paudel for cooperation during the study. I am also thankful to medical record officer Laxmi Raj Regmi for supporting in data review and Mr. Ram Bahadur Malla for his secretarial help.

\section{References}

1. Warrell DA. WHO/SEARO Guidelines for the clinical management of snake bites in the Southeast Asian region. South East Asian J Trop Med Publ Hlth 1999; 30:1- 83.

2. Chippaux JP. Snake-bites: appraisal of the global situation. Bull WHO 1998; 76 (5):515-24

3. Holve S. Envenomations: In Behrman RE, Kliegman RM, Jenson HB and Stanton BF. Nelson Textbook of Pediatrics. 18th ed. Philadelphia: W.B. Saunders Company; 2007: 2932-35.

4. Kasturiratne A, Wickremasinghe AR, de Silva N, Gunawardena NK, Pathmeswaran A et al. The global burden of snakebite: a literature 
analysis and modelling based on regional estimates of envenoming and deaths. PloS Med 2008;5(11):218.

5. Epidemiology and Disease Control Division, Ministry of Health, Gov of Nepal. Annual Report on Incidence of poisonous snakebite in Nepal. 2001:63-71.

6. WHO. Zoonotic Disease Control: Baseline Epidemiology Study on Snakebite, Treatment and Management in Nepal. WHO Weekly Epidemiol Rev 1987;42:319-20

7. Sharma SK, Chappuis F, Jha N, Bovier PA, Loutan L, Koirala S. Impact of snake bites and determinants of fatal outcomes in southeastern Nepal. Am J Trop Med Hyg 2004;71(2):234-8.

8. Shah KB, Shrestha JM, and Thapa CL. Department of Health Services Epidemiology and Disease Control Division, Zoonoses Control SubSection. Snakebite Management Guideline. 2003: $1-53$.

9. Hansdak SG, Lallar KS, Pokharel P, Shyangwa P, Karki P, Koirala SA. Clinico- epidemiological study of snakebite in Nepal. Trop Doctr 2004;34(1):20-2.

10. Pandey DP, Thapa CL, Hamal PK. Impact of First Aid Training in Management of Snake Bite Victims in Madi Valley. J Nepal Health Res Council 2010;8(16):5-9.

11. Heap BJ, Cowan GO. The epidemiology of snakebite presenting to British Military Hospital, Dharan, during 1989. J Army Med Corps 1991; 137:123-25.

12. Shrestha BM. Snakebite poisoning in children. JNepal Med Assoc 2002;41:463-67.

13. Sharma SK, Khanal B, Pokhrel P, Khan A, Koirala S. Snakebite-reappraisal of the situation in eastern Nepal. Toxicon. 2003;41:285-89.
14. Joshi DD. An Epidemiological Study of Snake Bite Cases in Children of Nepal. J Nep Paedtr Soc 2010;30(3):135-40.

15. Pandey DP. Epidemiology of Snake Bites Based on Hospital Survey in Chitwan and Nawalparasi Districts, Nepal. J Nep Health Res Counc 2006;4:51-57.

16. Simpson ID. The pediatric management of snakebite: the national protocol. Indian Pediatr 2007;44(3):173-6.

17. Ghosh S, Maisnam I, Murmu BK, Mitra PK, Roy A, Simpson ID. A Locally Developed Snakebite Management Protocol Signifi cantly Reduces Overall Anti Snake Venom Utilization in West Bengal, India. Wilderness Environmen Med 2008;19:267-74.

18. Warrell DA. WHO/SEARO Guidelines for the clinical management of snake bites in the Southeast Asian region. 2010.

19. Kulkarni ML, Anees S. Snake venom poisoning: experience with 633 cases. Indian Pediatr 1994;31:1239-43.

20. Devkota UN, Steinman JP, Kathayat JB. Epidemiology of snakebite; A study from Choharwa Army Camp, Siraha, Nepal. J Nepal Med Assoc 2001;40:57-62.

21. Devkota UN; Steinmann JP; Shah LN. Snakebite in Nepal: a study from Siraha district. $J$ Nepal Med Assoc 2000;39:203-09.

22. Paudel KM, Sharma S. Study of Clinicoepidemiologocal Profile and outcome of poisonous snake bites in Children. Journal of Nepal Paediatric Society 2012;32(1):47-52.

Correspondence Address: Dr. Kiran Mani Paudel, Chief Consultant Pediatrician, Department of Pediatrics, Lumbini Zonal Hospital, Rupandehi, Nepal. Email: kmp2588@yahoo.com 